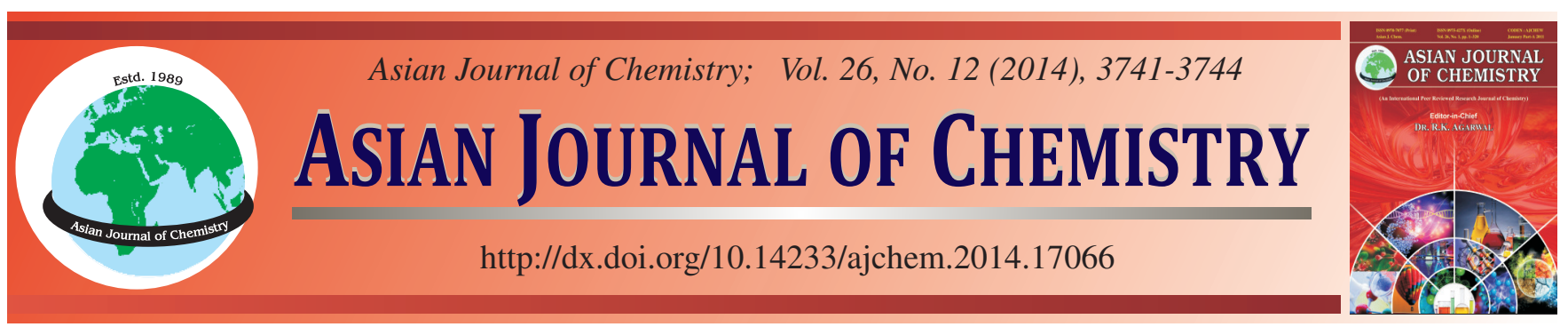

\title{
Anticancer and Antioxidant Activity of Ethanolic Extract of Markhamia lutea (Benth) K. Schum Stem Bark $\dagger$
}

\author{
R. NARENDRAN ${ }^{1, *}$, A. Ragamanvitha ${ }^{2}$, K.P. Arun $^{1}$ and P. Brindha ${ }^{1}$
}

${ }^{1}$ Centre for Advanced Research in Indian System of Medicine, SASTRA University, Thanjavur-613 401, India

${ }^{2}$ School of Chemical and Biotechnology, SASTRA University, Thanjavur-613 401, India

*Corresponding author: E-mail: carism.naren@gmail.com

\begin{abstract}
From time immemorial plants have been used to treat various diseases. Drug discovery from medicinal plants has played an important role in the treatment of cancer and, indeed, new clinical applications of plant secondary metabolites and their derivatives have been attempted towards combating cancer. In the present study a Bignoniaceae member, Markhamia lutea (Benth) K. Schum is selected and its chemical as well as anticancer efficacy were studied, with a view to get a lead to develop a safe and efficacious anticancer herbal drug. Ethanolic extract of stem bark of this plant have been prepared and subjected to chemical analysis. Active molecules present in the extract were identified using GCMS and LCMS/MS analysis. Antioxidant activity was assessed using DPPH method. Anticancer activity was evaluated against EAC cells by using MTT assay. The selected plant revealed good antioxidant activity with $\mathrm{IC}_{50} \mathrm{value}$ of $169.0 \mu \mathrm{g} / \mathrm{mL}$ and anticancer activity with an $\mathrm{IC}_{50}$ value of $27.0 \mu \mathrm{g} / \mathrm{mL}$.
\end{abstract}

Keywords: Markhamia lutea, GC-MS, LC-MSMS, Antioxidant, Anticancer.

\section{INTRODUCTION}

From time immemorial plants have been used for treating various ailments. More than $50 \%$ of modern drugs existing in clinical use today are derived from natural products such as plants ${ }^{1}$. Literature review suggest that plants play a vital role in the prevention and treatment of cancer with the advancement in techniques and tools till date. Various anticancer molecules are identified from plants which evince their anticancer effect either by promoting apoptosis or by inhibiting cancer activating enzymes and hormones or by stimulating DNA repair mechanism or by promoting production of protective enzymes or by enhancing antioxidant status and immunity ${ }^{2}$. Such an anticancer molecule developed from a bignoniaceae member is $\beta$-lapachone and lapachol extracted from the bark of Tabebuia impetiginosa stand $^{3}$. Some of the interesting bioactive compounds reported from this family are Iridoid glycosides, phenylethanoid glycosides and lapachol ${ }^{4}$. This prompted us to select a Bignoniaceae member Markhamia lutea (Benth) K. Schum available in and around Bangalore. After proper identification and authentication the ethanolic extract of the stem bark of the selected plant drug was evaluated for its antioxidant and anticancer potentials. Active molecules like terpenoids, flavonoids, glycosides and steroids have been reported from the leaves of this plant ${ }^{4}$.

\section{EXPERIMENTAL}

The stem bark of Markhemia lutea was collected and air dried. The dried plant material was coarsely powdered using pulverizer. About $250 \mathrm{~g}$ of powdered stem bark was used for extraction. The defatted plant material was soaked in ethanol for $48 \mathrm{~h}$ at room temperature. Ethanol was removed by rotary vacuum evaporator. The extract obtained was collected and subjected to further analysis.

Preliminary phytochemical screening: Preliminary phytochemical screening of ethanolic extract of stem bark was done as per standard testual procedures ${ }^{5}$ and the results were presented.

GC-MS analysis: GC-MS analysis of stem bark of Markhamia lutea ethanolic extract was carried out on a GC clarus 500 Perkin Elmer system interfaced to a mass spectrometer (GC-MS) instrument employing the following conditions: column Elite-5 $\mathrm{m}$ fused silica capillary column with $30 \mathrm{~m}$ length and $0.25 \mu \mathrm{m}$ film thickness composed of $5 \%$ phenyl $95 \%$ dimethyl polysiloxane, helium (99.999\% purity) was used as carrier gas at a constant flow of $1 \mathrm{~mL} / \mathrm{min}$ and an 
injection volume of $1.0 \mu \mathrm{L}$ was employed (split ratio of 10:1) with injector temperature $270^{\circ} \mathrm{C}$; ion-source temperature $150{ }^{\circ} \mathrm{C}$. The oven temperature was programmed from $50{ }^{\circ} \mathrm{C}$, with an increase of $8^{\circ} \mathrm{C} / \mathrm{min}$, to $250^{\circ} \mathrm{C}$ hold for $5 \mathrm{~min}$. Mass spectra were taken at $70 \mathrm{eV}$ (electron ionization technique) at a scan interval of $0.2 \mathrm{~s}$ and fragments were scanned from 40-600 Da. Interpretation on mass spectrum GC-MS was conducted using the database of National Institute of Standard and Technology (NIST 2005) having more than 62,000 patterns. The spectrum of the separated components was compared with the spectrum of NIST library database. The identity of the spectra above $95 \%$ was needed for the identification of components.

LC MS/MS analysis: Molecular screening of compounds present in the extract was carried out using LC-HR-ESI-MS/ MS analysis (UHPLC Dionex C18 RP Acclaim $120 \AA$, 2.1 $\mathrm{mm} \times 150 \mathrm{~mm}, 3.0 \mu \mathrm{m}$ column, USA and MSMS Bruker Q-II TOF). Polar and semi polar compounds were separated and identified at $325 \mathrm{~nm}, 0.2 \mathrm{~mL} / \mathrm{min}$ flow rate, gradient mobile system start with $0.2 \mathrm{~min}$ at $1 \%$ acetonitrile and $99 \%$ water (1\% acetic acid) to $75 \% \mathrm{ACN}$ at 16 th min, this was brought to $100 \%$ acetonitrile at 19 th $\min$ to $5 \%$ acetonitrile at $21 \mathrm{st}$ min and was maintained at same condition till run ends at 23rd min. ESI in negative mode using following conditions: Nebulizer 30.5 psi with $6.0 \mathrm{~L} / \mathrm{min}_{2}$ flow, $\mathrm{m} / \mathrm{z}$ range: 50 $1000 \mathrm{~m} / \mathrm{z}$, Capillary voltage $4500 \mathrm{~V}$, dry heater temperature at $280{ }^{\circ} \mathrm{C}$ were performed to identify the molecules based on their monoisotopic masses.

\section{Free radical scavenging activity}

DPPH method: Free radical scavenging activity of ethanolic extract of Markhamia lutea stem bark was carried out using 2,2-diphenyl-1-picryl hydrazyl radical (DPPH) assay. $0.1 \mathrm{mM}$ solution of DPPH and $1 \mathrm{mg} / \mathrm{mL}$ concentration of extract in methanol was prepared. Prepared the sample in various concentrations and added DPPH solution to all the test solutions. An equal amount of DPPH was used as negative control. Butylated hydroxytoluene (BHT) was used as positive control. After adding DPPH to all the tubes, the set up kept in a dark condition at room temperature. Absorption was taken after $20 \mathrm{~min}$ at $515 \mathrm{~nm}$. The percentage inhibition was calculated using the following formula.

$$
\text { Inhibition }(\%)=100-\left(\frac{\mathrm{Abs}_{\text {sample }}}{\mathrm{Abs}_{\text {control }}}\right) \times 100
$$

A linear graph between concentrations vs. \% inhibition was plotted and $\mathrm{IC}_{50}$ value was calculated ${ }^{6}$.

Cytotoxicity studies: In vitro anticancer activity was carried out for ethanolic Extracts of Markhamia lutea against EAC cells (Ehrlich Ascites Carcinoma). EAC cells were grown in RPMI-1640 media (2nM L-glutamine, $10 \%$ heat-inactivated fetal bovine serum (FBS), $1 \%$ penicillin/streptomycin) at 37pC and $5 \% \mathrm{CO}_{2}$ to reach $80 \%$ confluence. $0.1 \times 10^{6} \mathrm{EAC}$ cells were treated with different concentration $(1000-1.95 \mu \mathrm{g} / \mathrm{mL})$ of ethanolic extract of selected plant in a 96well plates for $48 \mathrm{~h}$. MTT assay was used to evaluate the cytotoxicity potential of plant drug ${ }^{7}$. Formazan formed was then dissolved using $0.1 \%$ DMSO. The optical density (OD) of each well was measured using Epoch microplate spectrophotometer (BioTek, USA) set at $590 \mathrm{~nm}$ filter ${ }^{7}$.

\section{RESULTS AND DISCUSSION}

Phytochemical screening of ethanolic extract of Markhamia lutea stem bark revealed the presence of flavonoids, coumarins, phenols, sugars and terpenes (Table-1).

\begin{tabular}{|c|c|c|}
\hline \multicolumn{3}{|c|}{$\begin{array}{c}\text { TABLE-1 } \\
\text { PRELIMINARY PHYTOCHEMICAL } \\
\text { SCREEING OF ETHANOLIC EXTRACT }\end{array}$} \\
\hline Test & Procedure & $\begin{array}{c}\text { Ethanolic } \\
\text { extract }\end{array}$ \\
\hline Saponin & Extract + water & - \\
\hline Tannins & Extract + lead acetate solution & - \\
\hline Sugars & $\begin{array}{c}\text { Extract + Fehling's A and B solution + } \\
\text { heating }\end{array}$ & + \\
\hline Coumarins & Extract $+10 \% \mathrm{NaOH}$ & + \\
\hline Alkaloids & Extract+ acetic acid + Dragondroff reagent & - \\
\hline Quinones & Extract + conc. $\mathrm{H}_{2} \mathrm{SO}_{4}$ & + \\
\hline Sterols & $\begin{array}{c}\text { Extract }+\mathrm{CHCl}_{3}+\text { glacial acetic acid }+ \text { heat } \\
\text { and cool then add conc. } \mathrm{H}_{2} \mathrm{SO}_{4}\end{array}$ & - \\
\hline Flavonoids & Extract $+10 \% \mathrm{NaOH}$ & + \\
\hline Phenols & Extract + alcoholic $\mathrm{FeCl}_{3}$ & + \\
\hline Gums & Extract + water & - \\
\hline Proteins & Extract + picric acid & - \\
\hline Terpenes & Extract + tin + thionyl chloride & + \\
\hline
\end{tabular}

Preliminary screening gives the platform to understand the nature of compounds present in the extract. Fig. 1 shows the GCMS spectrum of ethanolic extract. There are 25 compounds identified from the stem bark which are presented in the Table-2. Among these compounds bezofuran 3,5-dihydro, cinnamaldehyde, 4H-pyran-4-one-2,3-dihydro-3,5-dihydroxy6-methyl, 2-furancarboxaldehyde-5-(hydroxymethyl) are known to possess antitumor, antiproliferative and antimicrobial activity $^{8}$.

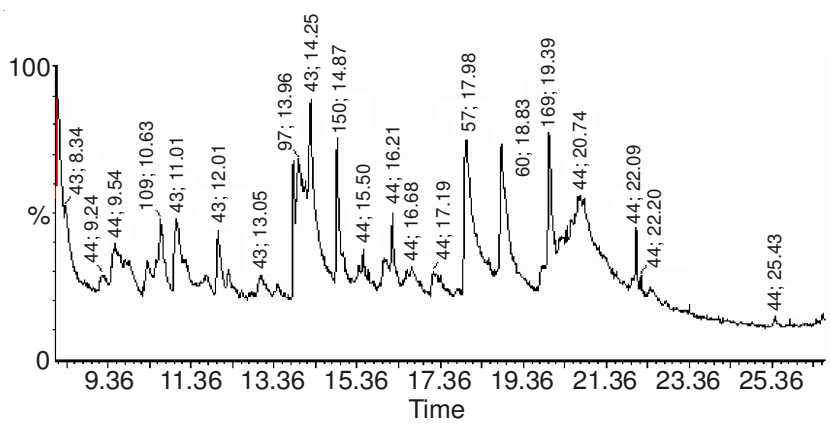

Fig. 1. GC-MS spectrum of ethanolic extract of $M$. lutea

LCMS/MS analysis suggested the presence of some anticancer molecules in the ethanolic extract. UV and MS spectrum of the extract was given in Figs. 2 and 3. Fig. 4 shows MS/MS pattern of the identified molecules. Molecules identified from LCMSMS are well known anticancer molecules such as oleanolic acid ( $m / z 456.7)$, pomolic acid $(m / z 472.69)$, musambin A $[\mathrm{M}-\mathrm{H}]^{-}(\mathrm{m} / \mathrm{z}$ 503) and $\beta$-sitosterol-3-O- $\beta$-D-glucopyranoside $(\mathrm{m} / \mathrm{z}$ 667.82). Among these compounds, pomolic acid is reported to induce apoptosis in HL-60 cells (Human promyelocytic leukemia cells) by activating caspases 3 and 9, it also alters mitochondrial transmembrane energy ${ }^{9}$. Pomolic acid activates the cyclic AMPK, inhibits cell proliferation and induces the apoptosis in MCF7 breast cancer cells ${ }^{10}$. Oleanolic acid inhibits the tumor cell proliferation of human colon cancer cell line 


\begin{tabular}{|c|c|c|c|}
\hline \multicolumn{4}{|c|}{$\begin{array}{c}\text { TABLE-2 } \\
\text { LIST OF COMPOUNDS IDENTIFIED FROM GC-MS ANALYSIS }\end{array}$} \\
\hline Peak name & Retention time & Peak area & Peak area $(\%)$ \\
\hline Name: Ethane, 1,1-diethoxy; m.f.: $\mathrm{C}_{6} \mathrm{H}_{14} \mathrm{O}_{2}$ m.w. 118 & 3.32 & 1186446 & 0.7957 \\
\hline Name: Propanoic acid, 2-oxo-, methyl ester; m.f.: $\mathrm{C}_{4} \mathrm{H}_{6} \mathrm{O}_{3}$, m.w.: 102 & 4.57 & 1604345 & 1.0759 \\
\hline Name: 1-Pentanol, 4-methyl; m.f.: $\mathrm{C}_{6} \mathrm{H}_{14} \mathrm{O}$, m.w.: 102 & 7.19 & 1176745 & 0.7892 \\
\hline Name: Phenol; m.f.: $\mathrm{C}_{6} \mathrm{H}_{6} \mathrm{O}$, m.w.: 94 & 9.24 & 2924907 & 1.9615 \\
\hline Name: Diglycerol; m.f.: $\mathrm{C}_{6} \mathrm{H}_{14} \mathrm{O}_{5}$, m.w.: 166 & 9.54 & 10589547 & 7.1017 \\
\hline Name: 2,5-Dimethyl-4-hydroxy-3(2H)-furanone; m.f.: $\mathrm{C}_{6} \mathrm{H}_{8} \mathrm{O}_{3}$, m.w.: 128 & 10.31 & 4783433 & 3.2079 \\
\hline Name: Mequinol; m.f.: $\mathrm{C}_{7} \mathrm{H}_{8} \mathrm{O}_{2}$; m.w.: 124 & 10.63 & 13055027 & 8.7552 \\
\hline Name: 1-Deoxy-d-altritol; m.f.: $\mathrm{C}_{6} \mathrm{H}_{14} \mathrm{O}_{5}$, m.w.: 166 & 11.71 & 2576385 & 1.7278 \\
\hline Name: 2-Amino-octadec-7-ene-1,3-diol butaneboronate; m.f.: $\mathrm{C}_{22} \mathrm{H}_{44} \mathrm{BNO}_{2}$, m.w.: 365 & 11.01 & 7660588 & 5.1375 \\
\hline Name: 4H-Pyran-4-one, 2,3-dihydro-3,5-dihydroxy-6-methyl; m.f.: $\mathrm{C}_{6} \mathrm{H}_{8} \mathrm{O}_{4}$, m.w.: 144 & 12.01 & 7687722 & 5.1557 \\
\hline Name: Cinnamaldehyde, (E); m.f.: $\mathrm{C}_{9} \mathrm{H}_{8} \mathrm{O}$, m.w.: 132 & 12.26 & 1703663 & 1.1425 \\
\hline Name: Benzoic acid, 2-hydroxy-, methyl ester; m.f.: $\mathrm{C}_{8} \mathrm{H}_{8} \mathrm{O}_{3}$, m.w.: 152 & 12.57 & 294570 & 0.1975 \\
\hline Name: 1,4:3,6-Dianhydro- $\alpha$-d-glucopyranose; m.f.: $\mathrm{C}_{6} \mathrm{H}_{8} \mathrm{O}_{4}$, m.w.: 144 & 13.45 & 1234557 & 0.8279 \\
\hline Name: Benzofuran, 2,3-dihydro; m.f.: $\mathrm{C}_{8} \mathrm{H}_{8} \mathrm{O}$, m.w.: 120 & 13.83 & 3753516 & 2.5172 \\
\hline Name: 2-Furancarboxaldehyde, 5-(hydroxymethyl); m.f.: $\mathrm{C}_{6} \mathrm{H}_{6} \mathrm{O}_{3}$, m.w.: 126 & 13.96 & 3850044 & 2.5820 \\
\hline Name: 2-Methoxy-4-vinylphenol; m.f.: $\mathrm{C}_{9} \mathrm{H}_{10} \mathrm{O}_{2}$, m.w.: 150 & 14.87 & 8750419 & 5.8684 \\
\hline Name: Endo-2,3-O-ethylidene- $\alpha$-d-erythrofuranose; m.f.: $\mathrm{C}_{6} \mathrm{H}_{10} \mathrm{O}_{4}$, m.w.: 146 & 15.63 & 205054 & 0.1375 \\
\hline Name: 1,4-Benzenediol, 2-methoxy; m.f.: $\mathrm{C}_{7} \mathrm{H}_{8} \mathrm{O}_{3}$, m.w.: 140 & 17.19 & 3441297 & 2.3079 \\
\hline Name: 1,3;2,5-Dimethylene-1-rhamnitol; m.f.: $\mathrm{C}_{8} \mathrm{H}_{14} \mathrm{O}_{5}$, m.w.: 190 & 17.98 & 33773640 & 22.6498 \\
\hline Name: D-Allose; m.f.: $\mathrm{C}_{6} \mathrm{H}_{12} \mathrm{O}_{6}$, m.w.: 180 & 18.83 & 22093308 & 14.8166 \\
\hline Name: Benzoic acid, 4-hydroxy-3-methoxy; m.f.: $\mathrm{C}_{8} \mathrm{H}_{8} \mathrm{O}_{4}$, m.w.: 168 & 19.86 & 848391 & 0.5690 \\
\hline Name: Phenol, 3,4,5-trimethoxy; m.f.: $\mathrm{C}_{9} \mathrm{H}_{12} \mathrm{O}_{4}$, m.w.: 184 & 19.99 & 9842982 & 6.6011 \\
\hline Name: $n$-Decanoic acid; m.f.: $\mathrm{C}_{10} \mathrm{H}_{20} \mathrm{O}_{2}$, m.w.: 172 & 21.98 & 146605 & 0.0983 \\
\hline Name: 3-Eicosene, (E); m.f.: $\mathrm{C}_{20} \mathrm{H}_{4} \mathrm{O}$, m.w.: 280 & 22.09 & 2530213 & 1.6969 \\
\hline Name: 4-((1E)-3-Hydroxy-1-propenyl)-2-methoxyphenol; m.f.: $\mathrm{C}_{10} \mathrm{H}_{12} \mathrm{O}_{3}$, m.w.: 180 & 22.43 & 1183675 & 0.7938 \\
\hline
\end{tabular}
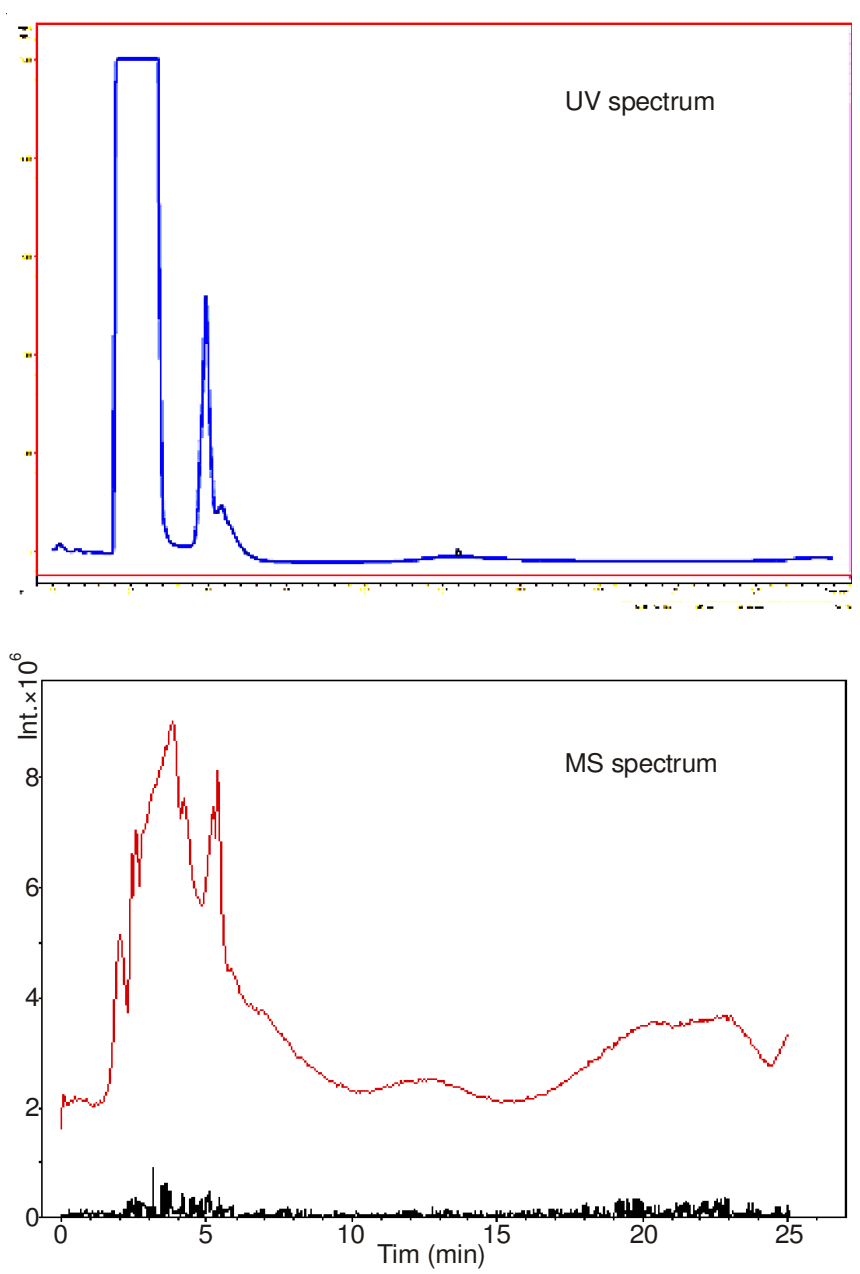

Fig. 2. UV and MS spectrum of ethanolic extract of markhamia lutea

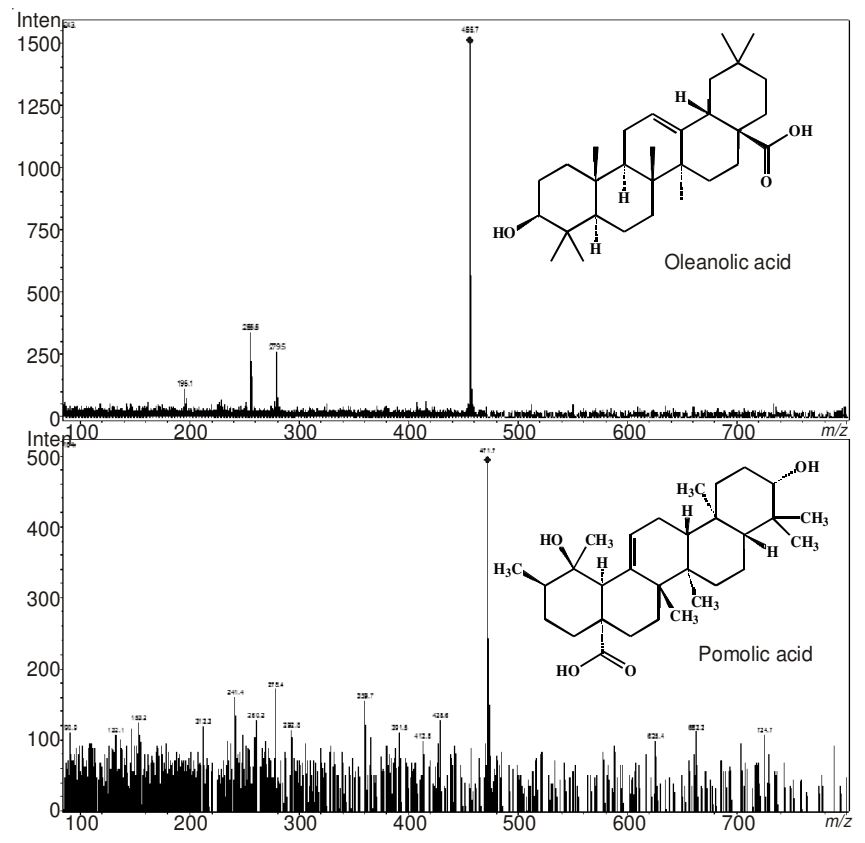

Fig. 3. MSMS pattern of oleanolic and pomolic acids

HCT15 by cell cycle arrest ${ }^{11}$. It also shows good angiogenic activity by strongly inhibiting the embryonic angiogenesis and capillary formation in chick embryo chorioallantoic membranes $^{12}$. A report on anticancer activity of musambin $\mathrm{A}$ on human fetal lung fibroblast (MRC-5) cells is also available ${ }^{4}$.

Antioxidant activity of ethanolic extract of Markhamia lutea stem bark was measured using DPPH assay. Fig. 5 shows the graph between the concentration and \% inhibition which suggests an $\mathrm{IC}_{50}$ value of $169 \mu \mathrm{g} / \mathrm{mL}$ revealing a good antioxidant activity of the ethanolic extract. 


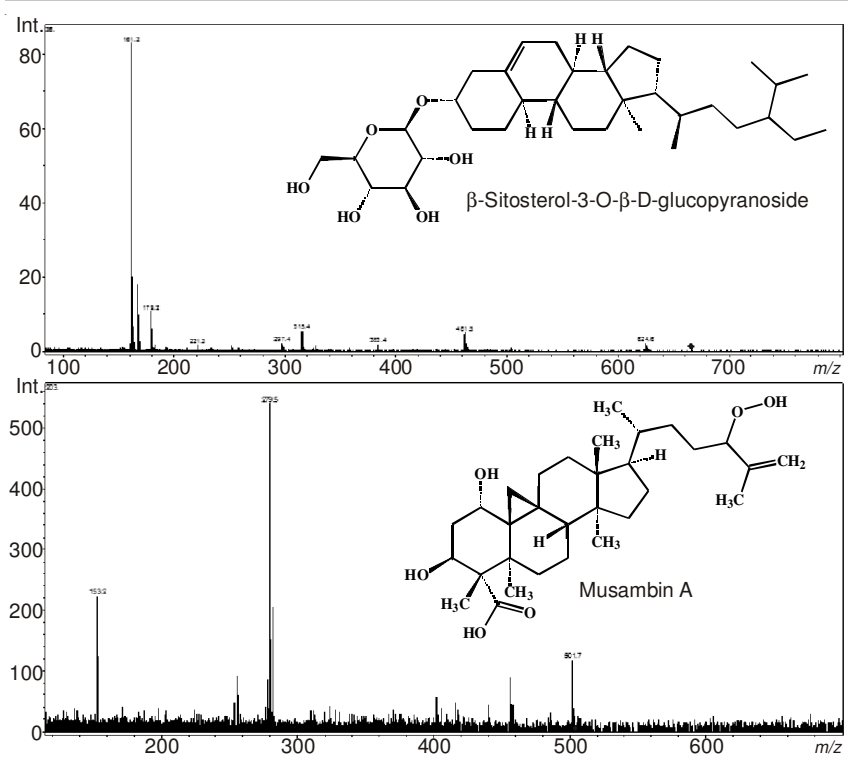

Fig. 4. MSMS pattern of $\beta$-sitosterol- $\beta$-glycopyranoside and musambin A

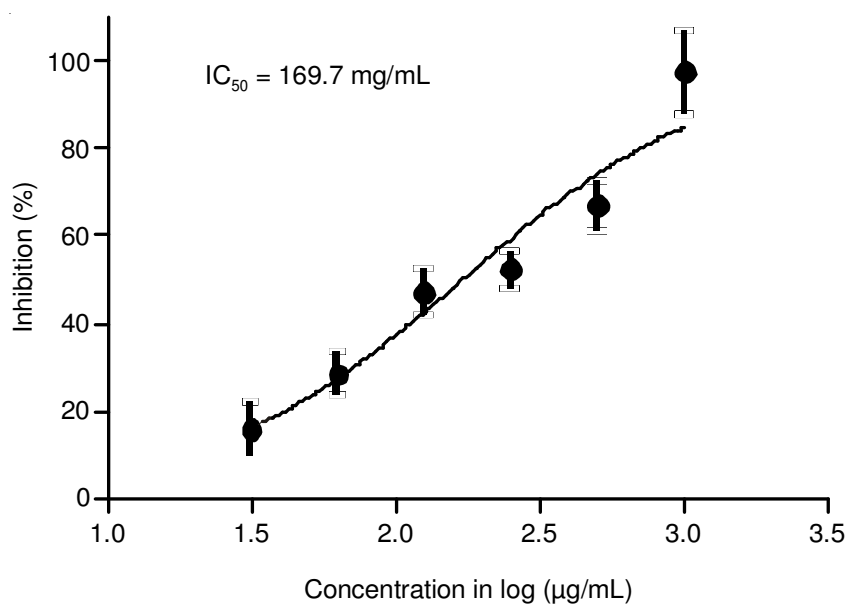

Fig. 5. DPPH assay for Antioxidant activity of ethanolic extract of Markhamia lutea stem bark

in vitro Anticancer activity of ethanolic extract against EAC cell lines was performed and the $\mathrm{IC}_{50}$ value is $27 \mu \mathrm{g} / \mathrm{mL}$. Fig. 6 indicates the plot of concentration and \% inhibition of the EAC cell growth. A drug with $\mathrm{IC}_{50}$ value below $30 \mu \mathrm{g} / \mathrm{mL}$ is suggested as a good anticancer agent.

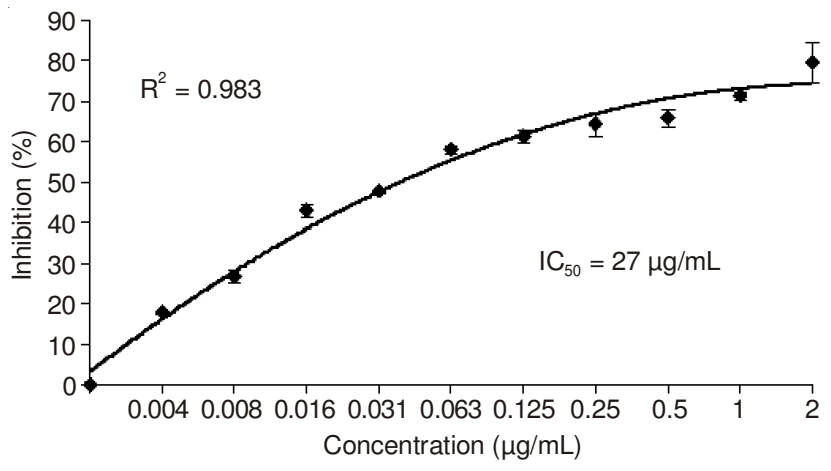

Fig. 6. MTT assay for anticancer activity of ethanolic extract of Markhamia lutea stem bark

\section{Conclusion}

The data depicted that the ethanolic extract of stem bark of Markhamia lutea posses good anticancer and antioxidant activity. This may be probably due to the presence of anticancer molecules with antioxidant potentials such as oleanolic acid, pomolic acid, $\beta$-sitosterol-3-O- $\beta$-D-glucopyranoside and musambin A present in the stem bark. Taking lead from the present work futher in-depth studies using this extract can be planned which can contribute significantly in the development of a novel herbal anticancer drug based on the Holistic approach.

\section{REFERENCES}

1. S. Sivalokanathan, M. Ilayaraja and M.P. Balasubramanian, Indian J. Exp. Biol., 43, 264 (2005).

2. D.M. Sakarkar and V.N. Deshmukh, Int. J. Pharm. Tech. Res., 3, 298 (2011).

3. W.C. Evans, Trease and Evans Pharmacognosy, W.B. Saunders, edn 15, pp. 400-405 (2002).

4. D. Lacroix, S. Prado, A. Deville, S. Krief, V. Dumontet, J. Kasenene, E. Mouray, C. Bories and B. Bodo, Phytochemistry, 70, 1239 (2009).

5. J.B. Harborne, Phytochemical Methods: A Guide to Modern Techniques of Plant Analysis, Chapman and Hall, pp. 1-89 (1949).

6. A. Yadav, R. Bhardwaj and R.A. Sharma, Int. J. Pharm. Pharm. Sci., 5, 489 (2013).

7. T. Mosmann, J. Immunol. Methods, 65, 55 (1983).

8. S. Ramalakshmi and K. Muthuchelian, Int. J. Chem. Tech. Res., 3, 1054 (2011).

9. J. Fernandes, R. Weinlich, R. Oliveiracastilho, M. Coelhokaplan, G. Amarantemendes and C. Gattass, Cancer Lett., 219, 49 (2005).

10. S.H. Youn, J.S. Lee, M.S. Lee, E.Y. Cha, P.T. Thuong, J.R. Kim and E.S. Chang, Biol. Pharm. Bull., 35, 105 (2012).

11. J. Li, W.J. Guo and Q.Y. Yang, World J. Gastroenterol., 8, 493 (2002).

12. K.-H. Sohn, H.-Y. Lee, H.-Y. Chung, H.-S. Young, S.-Y. Yi and K.-W. Kim, Cancer Lett., 94, 213 (1995). 